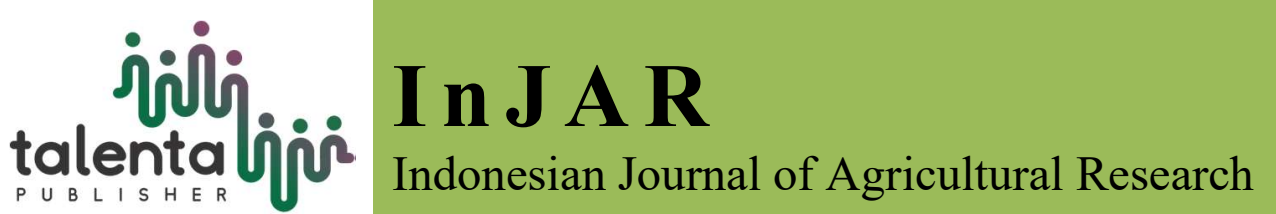

\title{
Effect of Ratio of Moringa Leaves Juice with Pineapple Juice and Arabic Gum on the Quality of Jelly Candy
}

\author{
Carly Frengky Purba, Hotnida Sinaga, and Mimi Nurminah \\ Department of Food Science and Technology, Faculty of Agriculture, Universitas Sumatera Utara, \\ Indonesia
}

\begin{abstract}
The purpose of this research was to determine the effect of ratio of moringa leaves juice with pineapple juice and the best percentage of arabic gum on the quality of jelly candy. This research was using completely randomized design with two factors, i.e. : ratio of moringa leaves juice with pineapple juice $(\mathrm{K}):(100 \%: 0 \% ; 75 \%: 25 \% ; 50 \%: 50 \%$; $25 \%: 75 \% ; 0 \%: 100 \%)$ and arabic gum percentage $(\mathrm{G}):(1,0 \% ; 1,5 \% ; 2,0 \%)$. Parameters analyzed were moisture content, ash content, vitamin $\mathrm{C}$ content, total soluble solid, total acid, lightness value $\left(\mathrm{L}^{*}\right)$, hedonic organoleptic values of colour, flavour, taste, texture and score organoleptic values of colour and texture. The results showed that the ratio of of moringa leaves juice with pineapple juice had highly significant effect on ash content, vitamin $\mathrm{C}$ content, total acid, lightness value, hedonic organoleptic test of colour, flavour, taste and score organoleptic value of colour. The ratio of moringa leaves juice with pineapple juice (25\%:75\%) and 2,0\% arabic gum percentage produces the best quality of jelly candy based on hedonic organoleptic values of colour, flavour, taste, texture and score organoleptic values of colour and texture.
\end{abstract}

Keywords: Arabic gum, moringa leaves, jelly candy, pineapple

Received 12 July 2018 | Revised 04 August 2018 | Accepted 15 August 2018

\section{Introduction}

Moringa is a plant that originally grows in India, but now it is widely found in tropical climates. Kelor grows in the lowlands and highlands up to \pm 1000 meters above sea level. Moringa is widely planted as a frontier or fence in the yard or fields. Moringa leaves can be harvested after the plant grows to 1,5 to 2 meters which usually takes 3 months to 6 months [1].

The potentials contained in the leaf of moringa are high protein content, beta-carotene, vitamin $\mathrm{C}$, minerals, especially iron and calcium, some literature described kelor has 3 times protein content of an egg, 25 times iron content of spinach, 12 times calcium content of carrot and 2 times protein content of milk. Moringa plants contain chemicals, such as essential oils, emulsion, alkaloids and vitamin A [2].

*Corresponding author at: Department of Food Science and Technology, Universitas Sumatera Utara, Jl. Prof A

Sofyan 3, Medan, Indonesia

E-mail address: [hotnida.sinaga@uq.net.au] 
Pineapple has many benefits. Pineapple has a slightly acidic taste because it contains citric acid and malic acid. Pineapple also contains bromelin enzyme that serves to soften meat. Pineapple can neutralize urine, mouthwash and hangover [3]. The bromelain enzyme in pineapple acts as anti-inflammatory, helps breaking down food so it is more digestible in the stomach and inhibit the growth of cancer cells. The main part of the pineapple plant that's economically important is its fruit. Pineapple fruit, aside from consumed fresh can also be processed into various foods and beverages, such as jam, preserved fruit in syrup, and others. A lot of people like pineapple because of its sweet and sour flavour. Pineapple fruit is also nutritious.

Gum arabic is a natural polymer which consists mostly of high molecular weight polysaccharides and contains high calcium, magnesium, potassium, which breaks down into arabinose, galactose, ramnosa and glucuronic acid after hydrolysis [4]. The limit on using arabic gum for food products is the maximum limit of Good Manufacturing Practice, hereinafter referred to as the maximum GMP limit, the amount of food additives allowed to exist in sufficient quantities of food required to produce desired effect [5].

Jelly candy is a candy made from water or juice and gel-forming materials, which gives the clear transparent colour as well as having a certain suppleness with texture. Gel-forming material is commonly used among other things are, gelatin, carrageenan, and agar. Candy jelly is categorized as semi-wet food, therefore jelly candy is quickly damaged. The addition of preservatives is necessary to extend the period of its shelf life [6].

\section{Materials and Methods}

The study was conducted from January to February 2018 at the Food Technology Laboratory, Faculty of Agriculture, University of North Sumatra. The materials used in this study were moringa and ripe pineapple, sugar, gum arabic, agar, and boiled water obtained at Sore Traditional Market, Medan, North Sumatra. Reagents used in this study were $0.1 \mathrm{~N} \mathrm{NaOH}$ solution, $1 \%$ phenolptalein (pp) indicator, $3 \%$ oxalic acid solution, dye solution and aquadest.

\subsection{Making of Moringa Leaves Juice and Pineapple Juice}

Moringa leaves juice was made from green leaves, which were sorted and washed with water. Moringa leaves were blanched for 5 minutes. Then, moringa leaves were crushed with a blender with the ratio of moringa and boiled water that was equal to $1: 2$, then filtered by using filter cloth to obtain the moringa leaves juice. Ripe pineapple were peeled and washed with running water. Pineapple were blanched for 5 minutes and cut into small pieces. Pineapple were blended with the ratio of pineapple and boiled water that was equal to $2: 1$, then filtered by using filter cloth to obtain pineapple juice. 


\subsection{Making Jelly Candy}

Moringa leaves juice and pineapple juice were weighed in accordance with the treatment ratio of $\mathrm{K}_{1}(100 \%: 0 \%), \mathrm{K}_{2}(75 \%: 25 \%), \mathrm{K}_{3}(50 \%: 50 \%), \mathrm{K}_{4}(25 \%: 75 \%), \mathrm{K}_{5}(0 \%: 100 \%)$ as much as $300 \mathrm{~g}$, thereafter, $150 \mathrm{~g}$ of sugar was added. The mixture was heated and stirred at the same time until the temperature reached $80^{\circ} \mathrm{C}$. Then, $2 \mathrm{~g}$ of jelly powder was added, followed by arabic gum according to the treatment i.e. $\mathrm{G}_{1}(1.0 \%), \mathrm{G}_{2}(1.5 \%), \mathrm{G}_{3}(2.0 \%)$. The heating and stirring process were continued until the mixture temperature reached $90^{\circ} \mathrm{C}$. Afterward, the mixture was placed into jelly mold and left for 1 hour at room temperature and sotred in the refrigerator at $10^{\circ} \mathrm{C}$ for 12 hours, followed by drying it on the oven at $50^{\circ} \mathrm{C}$ for 2 days. Candy jelly then packed on plastic clips and observed.

\subsection{Data Analysis}

This study used a complete randomized factorial design of 2 factors which were the ratio of moringa leaves juice with pineapple juice $(\mathrm{K})$ : $(100 \%$; $0 \%, 75 \%$; 25\%; 50\%: 50\%; 25\%: 75\%; $0 \%: 100 \%)$ and the percentage of gum arabic $(\mathrm{G}):(1.0 \%, 1.5 \%, 2.0 \%)$. The number of treatment combinations or Treatment Combination (Tc) was $3 \times 5=15$. Each treatment was made in 3 replications so the total sample size was 45 samples. Analyzed parameters were: moisture content, ash content, vitamin $\mathrm{C}$ content, total soluble solid, total acid, lightness value, hedonic organoleptic test of colour, flavour, taste and texture, and score test of colour and texture.

\subsubsection{Moisture content}

A sample of $5 \mathrm{~g}$ was put into an aluminum cup which had been dried for one hour at $105^{\circ} \mathrm{C}$ and weighed. The sample is heated at a temperature of $105^{\circ} \mathrm{C}$ for three hours, then cooled in the desiccator until it is cool then weighed. Heating and cooling are repeated until a constant sample weight is obtained (AOAC, 1995).

$$
\text { Moisture content }=\frac{\text { initial sample weight-final sample weigt }}{\text { initial sample weigh }} \times 100 \%
$$

\subsubsection{Ash content}

A sample of $5 \mathrm{~g}$ was inserted into a dry porcelain plate that was known to be of heavy weight (which was first burned in a furnace and cooled in a desiccator). Then the sample is sprinkled on top of the mecker burner for about 1 hour, first a small flame and then the flame is raised slowly until the sample changes to charcoal. Charcoal is put into the furnace with a temperature of $580^{\circ} \mathrm{C}-620^{\circ} \mathrm{C}$ until it forms ash. The cup containing the ash is transferred into the oven at a temperature of about $100^{\circ} \mathrm{C}$ for 1 hour. After that the cup containing the ash is cooled in the desiccator until it reaches room temperature and then weighed (Apriantono, et al., 1989). Calculated with the following formula:

$$
\text { Ash content }=\frac{\text { ash content }}{\text { sample content }} \times 100 \%
$$




\subsubsection{Vitamin $\mathrm{C}$ content}

Determined vitamin C levels of material with colourimetric method (Apriantono, et al., 1989).

\section{a. Dye solution and ascorbic acid}

The dye solution was made by weighing $100 \mathrm{mg}$ 2,6-dichlorophenol indofenol, then added 50 $\mathrm{ml}$ of hot aquadest and $84 \mathrm{mg}$ sodium bicarbonate. The solution was cooled and diluted to 100 $\mathrm{ml}$ of aquadest, then filtered and diluted $25 \mathrm{ml}$ of the solution to a volume of $500 \mathrm{ml}$ with aquadest. Standard ascorbic acid solution was prepared by weighing exactly $100 \mathrm{mg}$ of ascorbic acid and dissolving up to a volume of $100 \mathrm{ml}$ with $\mathrm{H} 2 \mathrm{C} 2 \mathrm{O} 4$ (oxalic acid) $2 \%$, diluted $4 \mathrm{ml}$ of the solution to a volume of $100 \mathrm{ml}$ with $\mathrm{H}_{2} \mathrm{C}_{2} \mathrm{O}_{4} \%(1 \mathrm{ml}=40 \mu \mathrm{g}$ ascorbic acid $)$.

\section{b. Sample preparation}

Sample preparation for analysis of ascorbic acid colourimetrically similar to sample preparation for analysis by titration, however $\mathrm{H}_{2} \mathrm{C}_{2} \mathrm{O}_{4}$ used concentrated at $2 \%$. If the sample to be analyzed is solid or semi solid, 50-100 g of sample is mixed with $6 \% \mathrm{H}_{2} \mathrm{C}_{2} \mathrm{O}_{4}$. Then diluted to a volume of $100 \mathrm{ml}$.

\section{c. Making standard curves}

Standard ascorbic acid is $40 \mu \mathrm{l}, 80 \mu \mathrm{l}, 100 \mu \mathrm{l}, 120 \mu \mathrm{l}$, and $160 \mu \mathrm{l}$ is pipetted into a $5 \mathrm{ml}$ tera flask. So obtained a concentration of $8 \mu \mathrm{g} / \mathrm{ml}, 16 \mu \mathrm{g} / \mathrm{ml}, 20 \mu \mathrm{g} / \mathrm{ml}, 24 \mu \mathrm{g} / \mathrm{ml}$, and $32 \mu \mathrm{g}$ / $\mathrm{ml}$. Then diluted with $2 \% \mathrm{H}_{2} \mathrm{C}_{2} \mathrm{O}_{4}$ to $5 \mathrm{ml}$ volume. Transferred into the test tube and then added $10 \mathrm{ml}$ of dye solution, homogenized and measured absorbance of the solution in spectrophotometry vis with a wavelength of $518 \mathrm{~nm}$. For blanks dye solution is used and absorbance is measured with a wavelength of $518 \mathrm{~nm}$. Then an absorbance vs. concentration curve is created.

\section{d. Sample measurement}

Weighed the sample as much as $5 \mathrm{~g}$, then put it into a $100 \mathrm{ml}$ volumetric flask with the addition of $\mathrm{H}_{2} \mathrm{C}_{2} \mathrm{O}_{4} \%$ to the tera and stirred evenly. Taken as much as $5 \mathrm{ml}$ then diluted again with $\mathrm{H}_{2} \mathrm{C}_{2} \mathrm{O}_{4} 2 \%$ until it reaches a volume of $100 \mathrm{ml}$ on a volumetric flask. Dilution results were taken as much as $5 \mathrm{ml}$ and put into a test tube and then added with a $10 \mathrm{ml}$ dye solution then the absorbance was measured with a wavelength of $518 \mathrm{~nm}$ and the absorbance results were recorded. The content of ascorbic acid in the sample can be calculated by the formula:

$$
\text { Vitamin } \mathrm{C} \text { content }=\frac{\text { ascorbic acid contentration } \mathrm{x} \text { total extract volume } \mathrm{x} \text { diluent factor }}{\text { sample volume } \mathrm{x} 1000 \mathrm{x} \text { sample weight }} \times 100
$$

\subsubsection{Total soluble solid}

The total soluble solid (TSS) are determined by the method of Sudarmadji, et al., (1997). A sample of $5 \mathrm{~g}$ is inserted into a glass beaker. Add distilled water to a volume of $20 \mathrm{ml}$ then stir 
until evenly distributed. Taken one drop of solution and dripped in a handrefractometer and then looked at the number at the point of light and dark.

Total soluble solids $\left({ }^{\circ}\right.$ Brix $)=$ number of handrefractometer $\mathrm{x}$ diluent factor

\subsubsection{Total acid}

Total acid is determined by the method of Ranganna (1978). The material was weighed $5 \mathrm{~g}$, put into a glass beaker. Then stirring evenly and filtered with a cotton funnel into a $100 \mathrm{ml}$ tera flask, dilution is done 1000 times. The results of dilution as much as $10 \mathrm{ml}$ were put into erlenmeyer then phenolphthalein $1 \%$ indicator was added as much as $2-3$ drops and titrated with $0.01 \mathrm{~N}$. NaOH. Titration was stopped after discolouration became violet red.

$$
\text { Total acid }(\%)=\frac{\mathrm{NaOH} \text { volume } \times \mathrm{N} \mathrm{NaOH} \times \text { dominant acid molecular weight } \times \text { diluent factor }}{\text { sample content }(\mathrm{g}) \times 1000 \times \text { acid valence }} \times 100 \%
$$

\subsubsection{Lightness value}

Colour was measured using a Minolta chromameter (CR 400 type, Japan). The sample is placed in the available container, then the start button is pressed and the values of $\mathrm{L}^{*}$, $a$, and $b$ will be obtained from the sample with a range of 0 (black) to \pm 100 (white). The notation "a" states the chromatic mixture of red-green with the value "+ a" (positive) from 0 to +100 for red and the value "-a" (negative) from 0 to - 80 for green. The "b" notation represents the blue-yellow chromatic colour with the value "+ b" (positive) from 0 to +70 for yellow and the value "-b" (negative) from 0 to -80 for blue. Whereas L states colour lightness. The higher the colour lightness, the higher the value of $L^{*}$ (Hutchings, 1999).

\subsubsection{Hedonic organoleptic test of colour, flavour, taste and texture}

Organoleptic assessment of colour, flavour, taste, and texture is done with a hedonic test. The trick is that the sample that has been given a code is randomly tested by 15 panelists. Tests are carried out sensually (organoleptic) which is determined based on a numerical scale (Soekarto, 1985). The hedonic scale used is like Table 1.

Table 1. Hedonic Scale of Colour, Flavour, Taste and Texture

\begin{tabular}{cc}
\hline Scale & Numerical scale \\
\hline Very like & 5 \\
Like & 4 \\
Rather like & 3 \\
Dislike & 2 \\
Very dislike & 1 \\
\hline
\end{tabular}

\subsubsection{Score organoleptic test of colour and texture}

Organoleptic test of jelly candy colour was carried out by colour score test, carried out by panelists as many as 15 people. Tests carried out sensually (organoleptic) with a range of scales given 1 to 5. Organoleptic test of jelly candy texture was carried out by texture score test, 
carried out by panelists as many as 15 people. Tests carried out sensually (organoleptic) with a range of scales given 1 to 5 (Soekarto, 1985).

Table 2. Colour and Texture Score (Numeric) Test Scale

\begin{tabular}{cll}
\hline Score & \multicolumn{1}{c}{ Colour } & \multicolumn{1}{c}{ Texture } \\
\hline 5 & Yellow & Very chewy \\
4 & Greenish Yellow & Chewy \\
3 & Green & Rather chewy \\
2 & Dark Green & Not Chewy \\
1 & Blackish Green & Very not chewy \\
\hline
\end{tabular}

\section{Results and Discussions}

In general, the results of the research showed that the ratio of moringa leaves juice with pineapple juice and percentage of gum arab gave an effect on the parameters observed in Table 3 and Table 4.

Table 3. Ratio of moringa leaves juice with pineapple juice to observed parameters

\begin{tabular}{|c|c|c|c|c|c|}
\hline \multirow{3}{*}{ Parameters } & \multicolumn{5}{|c|}{ Ratio of moringa leaves juice with pineapple juice } \\
\hline & $K_{1}$ & $K_{2}$ & $\mathbf{K}_{3}$ & $\mathbf{K}_{4}$ & $\mathbf{K}_{5}$ \\
\hline & $(100 \%: 0 \%)$ & $(75 \%: 25 \%)$ & $(50 \%: 50 \%)$ & $(25 \%: 75 \%)$ & $(0 \%: 100 \%)$ \\
\hline $\begin{array}{l}\text { Moisture content } \\
(\%)\end{array}$ & 20,0343 & 20,8087 & 20,6348 & 20,1395 & 20,2472 \\
\hline Ash content (\%) & $0,6797^{\mathrm{aA}}$ & $0,5513^{\mathrm{bB}}$ & $0,4287^{\mathrm{cC}}$ & $0,3692^{\mathrm{dD}}$ & $0,3028^{\mathrm{eE}}$ \\
\hline $\begin{array}{l}\text { Vitamin } \mathrm{C} \text { content } \\
\text { (mg/100g of } \\
\text { material) }\end{array}$ & $46,7187^{\mathrm{aA}}$ & $46,4802^{\mathrm{bB}}$ & $46,4507^{\mathrm{bB}}$ & $46,3906^{\mathrm{bB}}$ & $46,1677^{\mathrm{cC}}$ \\
\hline $\begin{array}{l}\text { Total soluble solid } \\
\left({ }^{\circ} \text { Brix }\right)\end{array}$ & 68,9690 & 67,1073 & 68,2571 & 69,6034 & 69,9583 \\
\hline Total acid (\%) & $2,5347^{\mathrm{cB}}$ & $2,5433^{\mathrm{bcB}}$ & $2,5500^{\mathrm{bcB}}$ & $2,8169^{\mathrm{bB}}$ & $3,7750^{\mathrm{aA}}$ \\
\hline Lightness (L*) & $31,7767^{\mathrm{bB}}$ & $31,8278^{\mathrm{bB}}$ & $32,4222^{\mathrm{bB}}$ & $33,6444^{\mathrm{bB}}$ & $38,4222^{\mathrm{aA}}$ \\
\hline $\begin{array}{l}\text { Hedonic } \\
\text { organoleptic value } \\
\text { of colour }\end{array}$ & $3,2889^{\mathrm{cC}}$ & $3,4000^{\mathrm{cC}}$ & $3,6222^{\mathrm{bB}}$ & $3,7852^{\mathrm{aAB}}$ & $3,9259^{\mathrm{aA}}$ \\
\hline $\begin{array}{l}\text { Hedonic } \\
\text { organoleptic value } \\
\text { of flavour }\end{array}$ & $2,7259^{\mathrm{eE}}$ & $3,1259^{\mathrm{dD}}$ & $3,5778^{\mathrm{cC}}$ & $4,1704^{\mathrm{bB}}$ & $4,4963^{\mathrm{aA}}$ \\
\hline $\begin{array}{l}\text { Hedonic } \\
\text { organoleptic value } \\
\text { of taste }\end{array}$ & $3,5630^{\mathrm{cC}}$ & $3,5852^{\mathrm{cC}}$ & $3,6519^{\mathrm{cC}}$ & $4,0519^{\mathrm{bB}}$ & $4,2741^{\mathrm{aA}}$ \\
\hline $\begin{array}{l}\text { Hedonic } \\
\text { organoleptic value } \\
\text { of texture }\end{array}$ & 3,8370 & 3,7852 & 3,8593 & 3,8222 & 3,8889 \\
\hline $\begin{array}{l}\text { Score organoleptic } \\
\text { value of colour }\end{array}$ & $2,1333^{\mathrm{dD}}$ & $2,2815^{\mathrm{dD}}$ & $3,2000^{\mathrm{cC}}$ & $3,5778^{\mathrm{bB}}$ & $4,1185^{\mathrm{aA}}$ \\
\hline $\begin{array}{l}\text { Score organoleptic } \\
\text { value of texture }\end{array}$ & 3,6000 & 3,6148 & 3,6148 & 3,5778 & 3,6296 \\
\hline
\end{tabular}

Notes: Different letter notations in the same row show significantly different effects at the $5 \%$ level (lower case) and are very significant different at 1\% level (upper case) 
Table 4. Percentage of gum arabic to observed parameters

\begin{tabular}{|c|c|c|c|}
\hline \multirow{3}{*}{ Parameters } & \multicolumn{3}{|c|}{ Arabic gum percentage } \\
\hline & $\mathrm{G}_{1}$ & $\mathrm{G}_{2}$ & $\mathrm{G}_{3}$ \\
\hline & $(1,0 \%)$ & $(1,5 \%)$ & $(2,0 \%)$ \\
\hline Moisture content $(\%)$ & $18,4462^{\mathrm{cC}}$ & $20,6634^{\mathrm{bB}}$ & $22,0090^{\mathrm{aA}}$ \\
\hline Ash content $(\%)$ & $0,4133^{\mathrm{cC}}$ & $0,4707^{\mathrm{bB}}$ & $0,5151^{\mathrm{aA}}$ \\
\hline Vitamin $C$ content $(\mathrm{mg} / 100 \mathrm{~g}$ material) & 46,4557 & 46,5025 & 46,3664 \\
\hline Total soluble solid ( $\left.{ }^{\circ} \mathrm{Brix}\right)$ & 69,1597 & 69,5401 & 67,6373 \\
\hline Total acid (\%) & 2,8688 & 2,8755 & 2,7877 \\
\hline Lightness value $\left(\mathrm{L}^{*}\right)$ & 32,8980 & 33,6907 & 34,2673 \\
\hline Hedonic organoleptic value of colour & 3,6178 & 3,6000 & 3,5956 \\
\hline Hedonic organoleptic value of flavour & 3,5733 & 3,6444 & 3,6400 \\
\hline Hedonic organoleptic value of taste & 3,8000 & 3,8222 & 3,8533 \\
\hline Hedonic organoleptic value of texture & $3,7378^{\mathrm{cB}}$ & $3,8444^{\mathrm{bAB}}$ & $3,9333^{\mathrm{aA}}$ \\
\hline Score organoleptic value of colour & 3,0933 & 3,1644 & 2,9289 \\
\hline Score organoleptic value of texture & $3,3111^{\mathrm{cC}}$ & $3,6489^{\mathrm{bB}}$ & $3,8622^{\mathrm{aA}}$ \\
\hline
\end{tabular}

Notes: Different letter notations in the same row show significantly different effects at the $5 \%$ level (lower case) and are very significant different at $1 \%$ level (upper case)

\subsection{Moisture Content}

The treatment that has the highest water content was $\mathrm{G}_{3}$ treatment $(2,0 \%)$ at $22,0090 \%$ and the lowest moisture content in treatment $\mathrm{G}_{1}(1,0 \%)$ at $18,4462 \%$. The addition of the percentage of arabic gum caused a change in the moisture content of the product, the higher the percentage of arabic gum added, the higher the moisture content of the resulting jelly candy[7].

\subsection{Ash Content}

The treatment with the highest ash content was $\mathrm{K}_{1}(100 \%: 0 \%)$ treatment at $0,6797 \%$ and the lowest ash content was treatment $\mathrm{K}_{5}(0 \%: 100 \%)$ at $0,3028 \%$. The higher amount of moringa leaves juice added, the ash content of jelly candy produced was increased, it was caused by high content of ash of moringa leaves which was $2,2875 \%$, while the ash content of the pineapple was $0,2485 \%$. The higher the percentage of arabic gum added, the higher the content of ash candy, it happened so because arabic gum acted as a stabilizer and contains calcium as much as $1117 \mathrm{mg}, 292 \mathrm{mg}$ magnesium, and iron $2 \mathrm{mg}$ in every $100 \mathrm{~g}$ of arabic gum [8].

The combination of treatment between moringa leaves juice with pineapple juice and percentage of arabic gum gave a highly significant effect on ash content. Treatment of $\mathrm{K}_{1} \mathrm{G}_{3}$ candy jelly with $100 \%$ moringa leaves juice and 2,0\% arabic gum had the highest ash content from all treatment which was $0,7216 \%$, whereas treatment with result of the lowest ash content was $\mathrm{K}_{5} \mathrm{G}_{1}$ treatment with $100 \%$ pineapple and $1,0 \%$ Arabic gum was at $0,2530 \%$ and $\mathrm{K}_{5} \mathrm{G}_{2}$ with $1,5 \%$ arabic gum was at $0,2817 \%$. Ash content of the jelly candy increased as more moringa leaves juice and arabic gum were added [9]. Moringa leaves juice and arabic gum has high mineral content which can increase the ash content [8]. 


\subsection{Vitamin C content}

The treatment with the highest vitamin $\mathrm{C}$ content was $\mathrm{K}_{1}(100 \%$ : $0 \%)$ which was 46,7187 $\mathrm{mg} / 100 \mathrm{~g}$ and the lowest vitamin $\mathrm{C}$ content was $\mathrm{K}_{5}(0 \%$ : 100\%) which was $46,1677 \mathrm{mg} / 100 \mathrm{~g}$ of material. The higher the percentage of moringa leaves juice with pineapple juice, the higher the vitamin $\mathrm{C}$ content. This was because the moringa leaves have high levels of vitamin $\mathrm{C}$ content[10].

\subsection{Total Acid}

The treatment which has the highest total acid was $\mathrm{K}_{5}(0 \%: 100 \%)$ which was $3.78 \%$ material and treatments that have the lowest total acid were $\mathrm{K}_{1}(100 \%: 0 \%), \mathrm{K}_{2}(75 \%: 25 \%)$, and $\mathrm{K}_{3}$ $(50 \%: 50 \%)$. The higher the ratio of the pineapple juice the higher the total acid of the candy jelly, this was due to the high acid content in the pineapple. Pineapple has a high acid content, influenced by the level of pineapple maturity [11].

\subsection{Lightness Value $\left(L^{*}\right)$}

The treatment that has the highest brightness value was $\mathrm{K}_{5}(0 \%: 100 \%)$ which was 38.42 . The value of $\mathrm{L}^{*}$ indicates the lightness of the jelly candy, the higher the $\mathrm{L}^{*}$ value the lighter the colour of the candy jelly product. Jelly candy lightness was influenced by the ratio of moringa leaves juice with pineapple juice in the mixture, in which, the higher percentage of moringa leaves juice was added, the jelly candy becomes darker, while the higher the ratio of the pineapple juice added, the jelly candy produced had a lighter colour [12].

\subsection{Hedonic Organoleptic Test of Colour, Flavour, Taste and Texture}

Treatments that have the highest colour hedonic value were $\mathrm{K}_{5}(0 \%: 100 \%)$ and $\mathrm{K}_{4}(25 \%$ : $75 \%)$. Treatments that have the lowest colour value were $\mathrm{K}_{1}(100 \%: 0 \%)$ and $\mathrm{K}_{2}(75 \%: 25 \%)$. The higher the percentage of pineapple juice that was used, the higher the colour hedonic value, it was because the panelists love the bright colours produced from the pineapplehence increasing panelist acceptance of the candy jelly produced [13].

The treatment that has the highest flavour hedonic value was $\mathrm{K}_{5}(0 \%$ : $100 \%)$ which was 4,4963 and the treatment that has the lowest flavour hedonic value was $K_{1}(100 \%: 0 \%)$ which was 2,7259 . The addition of moringa leaves juice on the candy products will give rotten smell of the product [12].

The treatment that has the highest hedonic taste value was $\mathrm{K}_{5}(0 \%$ : $100 \%)$ which was 4,2741 . This was because the slightly acidic taste from the pineapple which was favored by the panelists. Citric acid contained in the pineapple gives a sour taste favored by the panelists, citric acid can spur taste on food products thus giving more value to the taste of food products [14]. 
The treatment that has the highest texture hedonic value was $\mathrm{G}_{3}$ treatment $(2,0 \%)$ which was 3,9600 and the lowest texture hedonic value at treatment $\mathrm{G}_{1}(1,0 \%)$ which was 3,7378 . Arabic gum is a type of stabilizer that is able to bind water to maintain and improve the texture of product [15].

\subsection{Score Organoleptic Test of Colour and Texture}

The treatment that has the highest colour score score was $\mathrm{K}_{5}(0 \%: 100 \%)$ which was 4,1185 . As more moringa leaves juice was added, jelly candy colour value decreases. The addition of moringa leaves juice turns the colour of the candy jelly into greenish. The higher the added moringa leaves juice, the more greenish the jelly candy became [12].

The treatment that has the highest texture score score was $\mathrm{G}_{3}$ treatment $(2,0 \%)$ which was 3,8622 and the lowest texture score value was treatment $\mathrm{G}_{1}(1,0 \%)$ which was 3,3111 . The higher the percentage of Arabic gum added, the chewier candy jelly produced. This was because the stabilizer can improve the texture and bind water, when more water was bound, it will form a good texture [15].

\section{Conclusion}

The results showed that the comparison of moringa leaves juice with pineapple juice gave very significant different effect on ash content, vitamin $C$ content, total acid, lightness $\left(L^{*}\right)$, hedonic organoleptic value of colour, flavour, taste, and score organoleptic value of colour. Based on hedonic organoleptic value of colour, flavour, taste, texture, score organoleptic values of colour and texture, Moringa leaves juice with pineapple juice ratio (25\%:75\%) with arabic gum percentage $2,0 \%$ yielding the best quality of jelly candy.

\section{REFERENCES}

[1] A. F. A. Razis, M. D. Ibrahim, and S. B. Kntayya, "Health Benefits of Moringa oleifera," Asian Pacific Journal of Cancer Preventionm, vol. 15, no. 20, pp. 8571-8576, 2014.

[2] A. Diantoro, M. Rohman, and H.T. Palupi, "Pengaruh penambahan ekstrak daun kelor(Moringa oleifera L.) terhadap kualitas yoghurt," Jurnal Teknologi Pangan, vol. 6, no. 2, pp. 59-66, 2015.

[3] I. Purwaningsih, "Potensi Enzim Bromelin Sari Buah Nanas (Ananas comosus) Dalam Meningkatkan Kadar Protein Pada Tahu," Jurnal Teknologi Laboratorium, vol. 6, no. 1, pp. 39-46, 2017.

[4] N. A. Almuslet, A. H. Elfatih, A. A. Al-Sayed, and G. A. M. Mohamed, "Diode Laser (532 $\mathrm{nm}$ ) induced grafting of polyacrylamide into gum Arabic," Journal of Physical Science, University of Science Malaysia, vol. 23, no. 2, pp. 43-53, 2012.

[5] BPOM RI, Peraturan Kepala Badan Pengawas Obat dan Makanan Republik Indonesia No. 24 Tahun 2013 Tentang Batas Maksimum Penggunaan Bahan Tambahan Pangan Penstabil. Jakarta, 2013. 
[6] M. Rismandari, T. W. Agustini, and U. Amalia, "Karakteristik Permen Jelly dengan Penambahan Iota Karagenan dari Rumput Laut Eucheuma spinosum," Indonesian Journal of Fisheries Science and Technology, vol 12, no 2, pp. 103-108, 2017.

[7] M. Widyaningtyas, and W. H. Susanto, "Pengaruh jenis dan konsentrasi hidrokoloid (carboxyl methyl cellulose, xanthan gum, dan karagenan) terhadap karakteristik mie kering berbasis pasta ubi jalar varietas ase kuning," Jurnal Pangan dan Agroindustri, vol.3, no 2, pp. 417-423, 2014

[8] Rabah and Abdalla, "Decolourization of acacia seyal Gum Arabic," Annual Conference of Postgraduate Studies and Scientific Research Hall, Khartoum, Republic of Sudan, 2012, no. 1 , pp. 33-37.

[9] S. Aminah, T. Ramdhan, and M.Yanis, "Kandungan nutrisi dan sifat fungsional tanaman kelor (Moringa oleifera)," Buletin Pertanian Perkotaan, vol. 5, no. 2, pp. 35-45, 2015.

[10] K. T. Mahmood, T. Mugal, and I. U1-Haq, "Moringa oleifera: a natural gift - A review," Journal of Pharmaceutical Sciences and Research, vol. 2, no. 11, pp. 775-781, 2011.

[11] T. Hutagalung, R. J. Nainggolan., and M. Nurminah, "Pengaruh Perbandingan Bubur Buah Nanas dengan Bubur Wortel dab Jenis Zat Penstabil terhadap Mutu Selai Lembaran," Jurnal Rekayasa Pangan dan Pertanian, vol. 4, no. 1, pp. 58-64, 2016.

[12] P. S. Rahmawati and A. C. Adi, "Daya terima dan zat gizi permen jeli dengan penambahan bubuk daun kelor (Moringa oleifera)," Media Gizi Indonesia, vol. 11, no. 1, pp. 86-93, 2016.

[13] A. Shakerardekani, "Consumer acceptance and quantitative descriptive analysis of pistachio spread," Journal of Agricultural Science and Technology, vol. 19, no. 1, pp. 8595, 2017.

[14] P. Varela and G. Ares, "Sensory profiling, the blurred line between sensory and consumer science. A review of novel methods for product characterization," Food Research International, vol. 48, no. 2, pp. 893-908, 2012.

[15] E. P. Ketaren, S. Ginting, and E. Julianti, "Pengaruh Perbandingan gum arab dengan pektin sebagai penstabil terhadap mutu selai wortel nenas," Jurnal Rekayasa Pangan dan Pertanian, vol. 5, no. 1, pp. 136-139, 2017. 